\title{
Customer Satisfaction towards Services of Public and Private Sector Banks
}

\author{
DR. R. HEPSIBA (PDF), UGC Post-Doctoral Fellow, Department of Commerce and Management \\ Studies, Andhra University, Visakhapatnam, India. hepsirepaka@gmail.com. \\ PROF. B MOHAN VENKATA RAM, Professor, Department of Commerce and Management \\ Studies, Andhra University, Visakhapatnam, India, bmohanvram@gmail.com.
}

\begin{abstract}
The satisfaction of the customers is very important factor in all service industries to enhance and improve the profitability and financial performance of the concern. Banking sector is purely financial service industry and the customer's satisfaction is much more important to run banking business successfully. The satisfaction level of the customers is varying due to different kinds of banking services. There are many factors that are responsible in the discrimination of the services for different types of banking customers and lead to uneven satisfaction level. In India, Private and Public sector banks are providing the financial services to the different types of customers in rural and urban areas.
\end{abstract}

Keywords- Financial performance, Customer's satisfaction, Uneven satisfaction, Discrimination.

\section{INTRODUCTION}

A primary role of banks is connecting those with funds, such as investors and depositors, to those seeking funds, such as individuals or businesses needing loans. A bank is the connection between customers that have capital deficits and customers with capital surpluses.

Banks distribute the medium of exchange. Banking is a business. Banks sell their services to earn money, and they must market and manage those services in a competitive field. Banks are financial intermediaries that safeguard, transfer, exchange, and lend money and like other businesses that must earn a profit to survive. Understanding this fundamental idea helps you to understand how banking systems work, and helps you understand many modern trends in banking and finance.

\section{OBJECTIVES}

- To know the customers satisfaction towards services of public and private sector banks.

- To offer a suggestive framework for improving their competitiveness.

\section{METHODOLOGY}

Primary data was collected through administering schedules and having discussions with the sample respondents. In order to elicit the customer satisfaction towards business services of four public sector banks (State Bank of India and Andhra Bank) and private sector banks (ICICI Bank and IndusInd Bank), a structured schedule is administered among a sample size of 500 customers in Visakhapatnam city. The schedules are canvassed in such a way that 125 customers from each bank.

\section{REVIEW OF LITERATURE}

D Mishra (1997) in his study on the performance of commercial banks in India choosing relevant parameters like quality of service, risk management, profitability etc. His conclusion is that the banks should try to increase quality, balance risk management, and optimise profitability in order to survive and succeed. He identifies four challenges for the bank namely competition, credit, customer and control.

Anthony T. Allred and H. Lon Addams, (2000) in this article, indicated that neither banks nor credit unions do a good job of surveying customer needs or retaining customers. Other results indicate that fifty per cent of total respondents surveyed reported that they had stopped using a financial service provider because of poor service performance. The vast majority of that group reported that their decision was made because a bank failed to provide adequate service.

Focus of Neetu Prakash's (2006) in this article, comprehensive study on "Growth of retail banking in India" is growth pattern of retail banking in India. Her argument is that even though the growth of Retail banking in India is very small compared to world standards, the growth and development of retail banking is an important milestone in the Indian banking sector development. She also finds that the performance of private sector banks is better than that of their public sector counterparts in the growth of retail banking.

Paritosh and Kavita (2012) the paper on "The impact of customer satisfaction on retail banking" conclude that the ATM, internet and branch office are the popular channels 
used by retail banking customers. The financial crisis has

their retail banks.

not affected the trust and relationship of customers with

\section{FINDINGS OF THE STUDY}

The field study was conducted and the major findings of the study areas follows

\section{Table-1: Decision to take bank account}

\begin{tabular}{|c|c|c|c|c|c|}
\hline Bank & On your own & $\begin{array}{l}\text { On advise } \\
\text { of bank officials }\end{array}$ & $\begin{array}{l}\text { At the instance } \\
\text { of friends/ relatives }\end{array}$ & Others & Total \\
\hline \multirow{3}{*}{ SBI } & 53 & 31 & 35 & 6 & 125 \\
\hline & 42.40 & 24.80 & 28.00 & 4.80 & 100.00 \\
\hline & 31.93 & 21.68 & 21.34 & 22.22 & 25.00 \\
\hline \multirow{3}{*}{ Andhra Bank } & 35 & 41 & 45 & 4 & 125 \\
\hline & 28.00 & 32.80 & 36.00 & 3.20 & 100.00 \\
\hline & 21.08 & 28.67 & 27.44 & 14.81 & 25.00 \\
\hline \multirow{3}{*}{ IndusInd Bank } & 30 & 34 & 50 & 11 & 125 \\
\hline & 24.00 & 27.20 & 40.00 & 8.80 & 100.00 \\
\hline & 18.07 & 23.78 & 30.49 & 40.74 & 25.00 \\
\hline \multirow{3}{*}{ ICICI Bank } & 48 & 37 & 34 & 6 & 125 \\
\hline & 38.40 & 29.60 & 27.20 & 4.80 & 100.00 \\
\hline & 28.92 & 25.87 & 20.73 & 22.22 & 25.00 \\
\hline \multirow{3}{*}{ Total } & 166 & 143 & 164 & 27 & 500 \\
\hline & 33.20 & 28.60 & $32.80-$ & 5.40 & 100.00 \\
\hline & 100.00 & 100.00 & 100.00 & 100.00 & 100.00 \\
\hline
\end{tabular}

An enquiry has been made with regard to the decision to take bank account and the results are furnished in Table1. About 33.20 percent of the total respondents revealed that personal consideration influence their decision to take bank account. However, 32.80 percent respondents said that they are influenced by their friends to take account. It is strange enough to observe that respondents are not much influenced by the bank people. In case of bank-wise analysis the public sector bank (SBI) recorded a major share of the respondents (42.40 percent) who have taken account by their own whereas in private sector banks IndusInd bank constitute the maximum share who are influenced by their friends. The above analysis suggests that the bank employees seems not involving in promoting their business, though they happen to be sources for disseminating information regarding retail bank products.

Table-2: Facilities given more importance

\begin{tabular}{|c|c|c|c|c|c|}
\hline Bank & Retail loan facilities & ATM facilities & Deposits & Online banking & Total \\
\hline \multirow{3}{*}{ SBI } & 22 & 52 & 16 & 35 & 125 \\
\hline & 17.60 & 41.60 & 12.80 & 28.00 & 100.00 \\
\hline & 28.95 & 27.51 & 18.82 & 23.33 & 25.00 \\
\hline \multirow{3}{*}{ Andhra Bank } & 20 & 46 & 32 & 27 & 125 \\
\hline & 16.00 & 36.80 & 25.60 & 21.60 & 100.00 \\
\hline & 26.32 & 24.34 & 37.65 & 18.00 & 25.00 \\
\hline
\end{tabular}




\begin{tabular}{|c|c|c|c|c|c|}
\hline \multirow{3}{*}{ IndusInd Bank } & 16 & 46 & 21 & 42 & 125 \\
\hline & 12.80 & 36.80 & 16.80 & 33.60 & 100.00 \\
\hline & 21.05 & 24.34 & 24.71 & 28.00 & 25.00 \\
\hline \multirow{3}{*}{ ICICI Bank } & 18 & 45 & 16 & 46 & 125 \\
\hline & 14.40 & 36.00 & 12.80 & 36.80 & 100.00 \\
\hline & 23.68 & 23.81 & 18.82 & 30.67 & 25.00 \\
\hline \multirow{3}{*}{ Total } & 76 & 189 & 85 & 150 & 500 \\
\hline & 15.20 & 37.80 & 17.00 & 30.00 & 100.00 \\
\hline & 100.00 & 100.00 & 100.00 & 100.00 & 100.00 \\
\hline
\end{tabular}

An enquiry has been made with regard to the facilities given more importance is enquired into and the results are furnished in Table-2. Out of 500 sample respondents 37.80 percent expressed that ATM facility are given more importance, followed by online banking with (30 percent) and deposits with about 17 percent respectively. Even in bank-wise analysis has confirms this trend where in public sector bank SBI bank constitute the major share for ATM facility with 41.60 percent and in private sector banks IndusInd bank constitute the major share with (36.80 percent) of respondents for ATM services and ICICI bank constitute the maximum share with 36.80 percent for online banking facility. This analysis reflects that the majority of the customers of public and private sector banks are giving importance to ATM and online banking facilities respectively.

Table-3: Accounts for their family members

\begin{tabular}{|c|c|c|c|}
\hline Bank & Yes & No & Total \\
\hline \multirow{3}{*}{ SBI } & 70 & 55 & 125 \\
\hline & 56.00 & 44.00 & 100.00 \\
\hline & 23.65 & 26.96 & 25.00 \\
\hline \multirow{3}{*}{ Andhra Bank } & 89 & 36 & 125 \\
\hline & 71.20 & 28.80 & 100.00 \\
\hline & 30.07 & 17.65 & 25.00 \\
\hline \multirow{3}{*}{ IndusInd Bank } & 66 & 59 & 125 \\
\hline & 52.80 & 47.20 & 100.00 \\
\hline & 22.30 & 28.92 & 25.00 \\
\hline \multirow{3}{*}{ ICICI Bank } & 71 & 54 & 125 \\
\hline & 56.80 & 43.20 & 100.00 \\
\hline & 23.99 & 26.47 & 25.00 \\
\hline \multirow{3}{*}{ Total } & 296 & 204 & 500 \\
\hline & 59.20 & 40.80 & 100.00 \\
\hline & 100.00 & 100.00 & 100.00 \\
\hline
\end{tabular}

It can be observed from Table-3 that, more than half of the sample respondents have the accounts for their family members (59.20 percent) while (40.80 percent) shared their opinion negatively. Even bank-wise analysis we can observe similar trend. Andhra bank constitute the major share (71.20 percent) followed by ICICI bank ( 57 percent) in having retail bank accounts for 
the family members of respondents. But the respondents of SBI (44 percent) and IndusInd bank (47.20 percent) are not having accounts for their family members. Hence it can be observed from the above analysis that most of the people now a days, are taking bank accounts for themselves as well as their family members depending on the service which suits their needs.

Table-4: E-Banking services used

\begin{tabular}{|c|c|c|c|c|c|}
\hline Bank & Online banking & Mobile banking & ATM & All above & Total \\
\hline \multirow{3}{*}{ SBI } & 31 & 31 & 47 & 16 & 125 \\
\hline & 24.80 & 24.80 & 37.60 & 12.80 & 100 \\
\hline & 25.83 & 23.13 & 29.56 & 18.39 & 25 \\
\hline \multirow{3}{*}{ Andhra Bank } & 29 & 25 & 43 & 28 & 125 \\
\hline & 23.20 & 20.00 & 34.40 & 22.40 & 100 \\
\hline & 24.17 & 18.66 & 27.04 & 32.18 & 25 \\
\hline \multirow{3}{*}{ IndusInd Bank } & 27 & 42 & 32 & 24 & 125 \\
\hline & 21.60 & 33.60 & 25.60 & 19.20 & 100 \\
\hline & 22.50 & 31.34 & 20.13 & 27.59 & 25 \\
\hline \multirow{3}{*}{ ICICI Bank } & 33 & 36 & 37 & 19 & 125 \\
\hline & 26.40 & 28.80 & 29.60 & 15.20 & 100 \\
\hline & 27.50 & 26.87 & 23.27 & 21.84 & 25 \\
\hline \multirow{3}{*}{ Total } & 120 & 134 & 159 & 87 & 500 \\
\hline & 24.00 & 26.80 & 31.80 & 17.40 & 100 \\
\hline & 100.00 & 100.00 & 100.00 & 100.00 & 100 \\
\hline
\end{tabular}

An enquiry regarding the e-banking services used by the retail bank customers (Table-4) revealed that about 32 percent of the respondents expressed their opinion that ATM service are more used by them, followed by mobile banking and online banking respectively. About 18 percent of the respondents expressed that they use all e-banking services when and wherever necessary. Even in public sector banks it is noticed the similar pattern where in SBI bank constitute the major share for ATM services with 37.60 percent and in IndusInd bank mobile banking constitute the major share (33.60 percent) of the total respondents. From the above, one may draw a conclusion that majority of the respondents are availing ATM service as ATM's provide service round the clock.

Table-5: E-Banking service comfortability

\begin{tabular}{|c|c|c|c|c|c|c|}
\hline Bank & $\begin{array}{l}\text { Online } \\
\text { Banking }\end{array}$ & $\begin{array}{l}\text { Mobile } \\
\text { banking }\end{array}$ & $\begin{array}{l}\text { Personal } \\
\text { computer } \\
\text { banking } \\
\end{array}$ & ATM & All above & Total \\
\hline \multirow{3}{*}{ SBI } & 23 & 39 & 3 & 43 & 17 & 125 \\
\hline & 18.40 & 31.20 & 2.40 & 34.40 & 13.60 & 100.00 \\
\hline & 28.05 & 21.91 & 11.11 & 34.68 & 19.10 & 25.00 \\
\hline \multirow{3}{*}{ Andhra Bank } & 16 & 51 & 12 & 24 & 22 & 125 \\
\hline & 12.80 & 40.80 & 9.60 & 19.20 & 17.60 & 100.00 \\
\hline & 19.51 & 28.65 & 44.44 & 19.35 & 24.72 & 25.00 \\
\hline IndusInd Bank & 22 & 43 & 7 & 26 & 27 & 125 \\
\hline
\end{tabular}




\begin{tabular}{|l|l|l|l|l|l|l|}
\hline & 17.60 & 34.40 & 5.60 & 20.80 & 21.60 & 100.00 \\
\cline { 2 - 7 } & 26.83 & 24.16 & 25.93 & 20.97 & 30.34 & 25.00 \\
\hline \multirow{4}{*}{ ICICI Bank } & 21 & 45 & 5 & 31 & 23 & 125 \\
\cline { 2 - 7 } & 16.80 & 36.00 & 4.00 & 24.80 & 18.40 & 100.00 \\
\cline { 2 - 7 } & 25.61 & 25.28 & 18.52 & 25.00 & 25.84 & 25.00 \\
\hline \multirow{3}{*}{ Total } & 82 & 178 & 27 & 124 & 89 & 500 \\
\cline { 2 - 7 } & 16.40 & 35.60 & 5.40 & 24.80 & 17.80 & 100.00 \\
\cline { 2 - 7 } & 100.00 & 100.00 & 100.00 & 100.00 & 100.00 & 100.00 \\
\hline
\end{tabular}

An enquiry has been made with regard to the opinion about e-banking service comfortability in four banks which are summarized in Table-5. It clearly indicates that out of 500 sample respondents nearly 36 percent respondents are comfortable with mobile banking service, followed by ATM service with 24.80 percent. Only 16.40 percent of the respondents are comfortable with online banking. Even the public and private sector bank also in conformity with this trend so far the share of mobile banking and ATM service in the total sample respondents are concerned, with an exception of SBI bank for which the ATM service constitute the major share followed by mobile banking service. It is pertinent to observe that 5.40 percent of the total respondents opinioned that they are comfortable with personal computer banking. It is also observed that the major share of the total mobile banking respondents (41 percent) are from Andhra bank. From the above analysis, it is presumed that the majority of the respondents are comfortable with mobile banking service offered by the four public and private sector banks.

\section{SUGGESTIONS}

The following suggestions are offered based on the findings drawn from the study as well as some general suggestions observed while doing the study.

[1] Banks should organize education campaigns through communication media such as posters, publications, radio, television, lectures, seminars, trainings etc., regarding security and privacy of their accounts.

[2] Some customers are hindered by lack of computer skills. They need to be educated on basic skills required to conduct online banking.

[3] Banks should have a sound network system; and there should be availability of IT personnel round the clock.

[4] Sincere and honest customers must be honoured on the public platforms to motivate the remaining customers.
[5] Public sector banks should improve their ebanking / internet banking services to compete with their private sector counterparts.

[6] Above all the banks should act as a friend, philosopher and guide to the borrowers and advise them through counselling to make their activities more productive and efficient.

\section{REFERENCES}

[1] Mishra, D. (1997). Fundamentals for Banks. IBA Bulletin, XIX (8), 42.

[2] Anthony, T. and Addams, H, "SQ at Banks and Credit Unions”, Managing SQ, 10(1), 2000, PP. 52-60.

[3] Neetu, Prakash. (2006). Retail Banking in India. ICFAI University Press, Hyderabad. 3-13.

[4] Paritosh, Awasthi. And Kavita, Dive. (2012).Impact of Customer's Satisfaction on Retail Banking, International Referred Research Journal, 3 (36), 15-16.

[5] Primary source 